\title{
PERSPECTIVE OPEN Biomass waste utilisation in low-carbon products: harnessing a major potential resource
}

\author{
Nimisha Tripathi ${ }^{1 *}$, Colin D. Hills $^{1 *}$, Raj S. Singh ${ }^{2 *}$ and Christopher J. Atkinson $\mathbb{D}^{3}$
}

The increasing demand for food and other basic resources from a growing population has resulted in the intensification of agricultural and industrial activities. The wastes generated from agriculture are a burgeoning problem, as their disposal, utilisation and management practices are not efficient or universally applied. Particularly in developing countries, most biomass residues are left in the field to decompose or are burned in the open, resulting in significant environmental impacts. Similarly, with rapid global urbanisation and the rising demand for construction products, alternative sustainable energy sources and raw material supplies are required. Biomass wastes are an under-utilised source of material (for both energy and material generation), and to date, there has been little activity focussing on a 'low-carbon' route for their valorisation. Thus, the present paper attempts to address this by reviewing the global availability of biomass wastes and their potential for use as a feedstock for the manufacture of high-volume construction materials. Although targeted at practitioners in the field of sustainable biomass waste management, this work may also be of interest to those active in the field of carbon emission reductions. We summarise the potential of mitigating $\mathrm{CO}_{2}$ in a mineralisation step involving biomass residues, and the implications for $\mathrm{CO}_{2}$ capture and utilisation (CCU) to produce construction products from both solid and gaseous wastes. This work contributes to the development of sustainable value-added lower embodied carbon products from solid waste. The approach will offer reduced carbon emissions and lower pressure on natural resources (virgin stone, soil etc.).

npj Climate and Atmospheric Science (2019)2:35

; https://doi.org/10.1038/s41612-019-0093-5

\section{INTRODUCTION}

Agricultural and forestry practices produce large amounts of wastes derived from harvestable yield. The global annual generation of biomass waste is in the order of $140 \mathrm{Gt}^{1,2}$ and this presents significant management problems, as discarded biomass can have negative environmental impacts.

Biomass waste streams are potential feedstocks for a variety of products ranging from the production of fuel, polymers and building products. It is the latter that is the focus of the present work, through an investigation of biomass waste arising and its combination with mineralised $\mathrm{CO}_{2}$ gas in the production of sustainable construction materials.

Agricultural biomass wastes/residues are predominantly crop stalks, leaves, roots, fruit peels and seed/nut shells that are normally discarded or burned but are in practice a potential valuable supply of feed-stock material. There are some challenges in trying to determine the extent of crop-produced biomass in relation to what is a 'loss' (from production, post harvesting and processing), or a 'waste' (retail or consumer loss). ${ }^{3}$ One significant issue is that the production of 'food' tends to be measured by the edible components of a crop (harvest index) and does not take into account non-edible biomass components, whether cropped or not. Crops such as sugarcane often require processing and this can generate secondary and tertiary waste streams in addition to the primary biomass waste realised upon harvesting. ${ }^{4}$ Thus, we assume that waste biomass is likely to be a reasonable consistent by-product from agricultural production for a given crop and geographical region. Particularly in developing countries, most biomass residues are not utilised or treated but left in the field to decompose naturally or be openly burned. That said, some waste residues generated from crops such as sugarcane, rice, groundand coffee nuts are used as a fuel source. ${ }^{5}$ Cellulose/hemicelluloses and lignin-rich residues can be used for the production of chemicals, resins and enzymes. ${ }^{6}$ Sugar bagasse, and less commonly rice husk and wheat chaff also have uses, but despite this, there is little valorisation of biomass waste currently practiced, ${ }^{7}$ and this important resource remains significantly under-utilised. Thus, as only a small amount of the biomass waste generated becomes a feedstock for industrial applications and electricity generation, the remaining adversely impacts the atmosphere, surface and ground-water quality and causes pestilence.

Of the huge quantities of annual global generation of agricultural residue, ${ }^{8,9}$ cereal crops are a major contributor. Globally, $66 \%$ of the residual plant biomass comes from cereal straw (stem, leaf and sheath material), with over $60 \%$ of these residues produced in low-income countries. ${ }^{10}$ Sugarcane stems and leaves are the second largest contributors, with other residual biomass including the 'oil crops', roots and tubers, nuts, fruits and vegetables. It should be noted that some of these have potential use in energy production.

In the EU, about $23 \mathrm{Mt} /$ p.a. of biomass (dry) is available as residual straw from cereals, ${ }^{11}$ whereas from example emerging economies like India, ca. $368 \mathrm{Mt} /$ p.a. straw residue is available, ${ }^{12}$ whilst China produces about 649 Mt (2009 figure). ${ }^{13}$ The major global crops (wheat, maize, rice, soybean, barley, rapeseed, sugarcane and sugar beet) in the selected countries/regions with large biomass potential (EU27, Pan Europe minus the EU27, United States of America, Canada, Brazil, Argentina, China and India) produce almost 3.3 Gt residue (fresh weight)/p.a. (Table 1).

\footnotetext{
${ }^{1}$ Indo:UK Centre for Environment Research and Innovation, University of Greenwich, Chatham Maritime, Kent ME4 4TB, UK. ${ }^{2}$ Indo:UK Centre for Environment Research and Innovation, CSIR-Central Institute of Mining and Fuel Research, Dhanbad ,2210015 Jharkhand, India. ${ }^{3}$ Natural Resources Institute, University of Greenwich, Chatham Maritime, Kent ME4 4TB, UK. These authors contributed equally: Colin D. Hills, Raj S. Singh. *email: n.tripathi@gre.ac.uk; c.d.hills@gre.ac.uk; rajcimfr@gmail.com
} 
Table 1. Cumulative generation potential of agricultural residues in selected countries

\begin{tabular}{ll}
\hline Country of origin & Amount of residue (Mt fresh weight) \\
\hline China & 716 \\
United States of America & 682 \\
India & 605 \\
Europe & 580 \\
Brazil & 451 \\
Argentina & 148 \\
Canada & 105 \\
Total & 3287 \\
\hline Source: ref. ${ }^{100}$ & \\
\hline
\end{tabular}

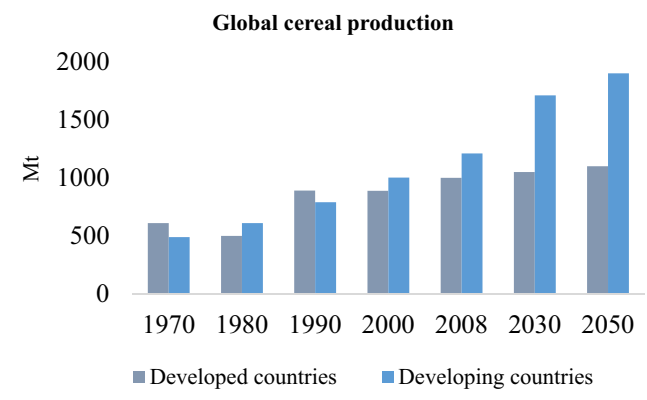

Fig. 1 Projected global demand for cereal crops

Currently, the global resource for unexploited cereal crop residues is ca. $517 \mathrm{Mt}^{5}$ The $\mathrm{FAO}^{14}$ projections from 1999 to 2030 suggest that the land used for agriculture in developing countries will increase by $13 \%$ or $120 \mathrm{M}$ ha. Global cereal yield is predicted to increase in the range of $0.9 \%$ over the period 2005/ 2007-2050, following a trend of long-term declining growth yield. ${ }^{15,16}$ As agricultural intensification (producing more per unit of land) will increase crop residues, ${ }^{17}$ agricultural productivity in 2050 is projected to be $60 \%$ higher than in $2005 / 2007 ;{ }^{18}$ for cereal production this equates to an increase of 1-billion tonnes (Fig. 1), partly met by growth in the developing countries. ${ }^{19}$

Of increasing importance is the use of oil crops, which have grown by $2.5 \%$ from 1999 to $2015 .^{20,21}$ In particilar, the major developing countries like China and India have intensified their oil crop production to meet increasing food demand, including for livestock. ${ }^{21}$ In Europe, the use of rapeseed for biofuel production is also rapidly increasing. ${ }^{22-24}$

The other sector of interest is forestry, which generates woody biomass residues from timber logging. FAO statistics show that global forests cover 4 B ha (about $30 \%$ of total land area), corresponding to an average of $0.62 \mathrm{ha} /$ capita. There is a further 1 $B$ ha of wooded land worldwide. ${ }^{25}$

Of the global $4 \mathrm{~B}$ ha of forest, around $50 \%$ falls within developing countries. ${ }^{26}$ Residue (e.g., stumps, branches and leaves) and processing waste (e.g., logs and sawdust) generation and recovery depends on factors such as tree species and local geographical conditions. ${ }^{27}$ For every cubic metre of logged material removed, a cubic metre of waste remains in the forest. ${ }^{28}$ Harvested timber is processed to produce different wood products. Initial processing waste includes branch trimming and bark removal (about $12 \%$ of this material arrives at the mill), slabs/ blocks/further trimmings (about 34\%) and sawdust (about 12\%). After kiln drying, shavings (about 6\%) and sawdust/trimming

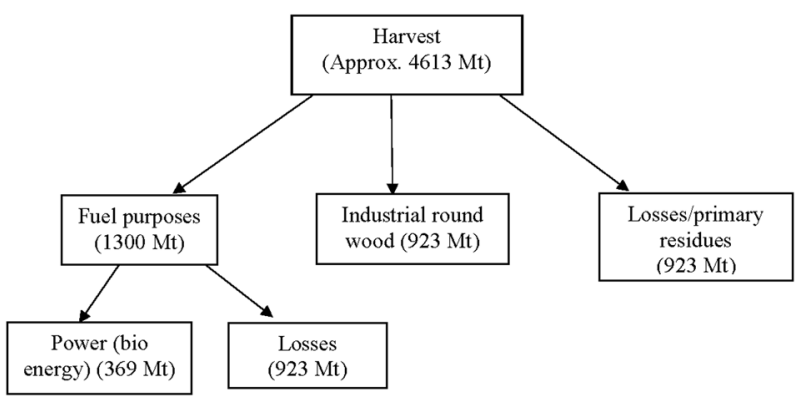

Fig. 2 Global allocation and flow of wood biomass

\begin{tabular}{|ll|}
\hline Table 2. Major global producers of forest residues \\
\hline Country of origin & $\begin{array}{l}\text { Potential forest stock residues (46\% of } \\
\text { total stock) (Mt) }\end{array}$ \\
\hline Russian Federation & 5718 \\
Indonesia & 2221 \\
USA & 2078 \\
Brazil & 1613 \\
China & 807 \\
Sweden & 316 \\
France & 308 \\
Finland & 246 \\
India & 232 \\
Philippines & 162 \\
Poland & 132 \\
Norway & 81 \\
Austria & 80 \\
Republic of Korea & 65 \\
South Africa & 52 \\
Canada & 50 \\
Thailand & 40 \\
UK & 15 \\
Japan & 0 \\
Germany & 0 \\
Austria & 0 \\
Subtotal of 21 top selected & 14,218 \\
countries & \\
\hline Source: ref. & \\
& \\
\hline
\end{tabular}

(about 2\%) add to the total amount of waste. ${ }^{29,30}$ The global allocation of wood biomass and its flow is shown in Fig. 2 .

The global production of wood-derived biomass is around 4.6 Gt annually of which $60 \%$ goes to energy generation, $20 \%$ to industrial 'round wood' and the remaining 20\% being primary production loss that remains in-field to decay. An estimated $80 \%$ of forest tree mass is lost as waste, with about $20 \%$ of the wood ending up in the form of kiln-dried sawn product. ${ }^{31}$ Based on $\mathrm{FAO}^{29}$ estimations, Table 2 gives the total residue reserves in productive forests for 21 countries, based on their production. Industrial wood from forest felling and sawmill residues for these countries is shown in Table $3 .{ }^{29,32}$ Of the total estimated at $715 \mathrm{Mt} /$ p.a., the potential residues produced are more than $700 \mathrm{Mt} / \mathrm{p} . \mathrm{a} ., \mathrm{a}$ loss that could be used, for example, as a source of fuel. ${ }^{11,32}$ 
Table 3. Global industrial wood production and calculated fresh residue mass

\begin{tabular}{|c|c|c|c|}
\hline $\begin{array}{l}\text { Country } \\
\text { of origin }\end{array}$ & $\begin{array}{l}\text { Residue from } \\
\text { forest felling and } \\
\text { cutting (Mt) }\end{array}$ & $\begin{array}{l}\text { Residue } \\
\text { from saw } \\
\text { mills (Mt) }\end{array}$ & $\begin{array}{l}\text { Total potential } \\
\text { residue from } \\
\text { industrial wood } \\
\text { production, } \\
2013^{\mathrm{a}}(\mathrm{Mt})\end{array}$ \\
\hline USA & 111.8 & 44.0 & 155.8 \\
\hline $\begin{array}{l}\text { Russian } \\
\text { Federation }\end{array}$ & 68.5 & 27.0 & 95.5 \\
\hline Brazil & 59.1 & 23.3 & 82.3 \\
\hline Canada & 56.2 & 22.1 & 78.4 \\
\hline China & 5504 & 21.8 & 77.2 \\
\hline Indonesia & 25.2 & 9.9 & 35.1 \\
\hline Sweden & 23.8 & 9.4 & 33.2 \\
\hline India & 19.8 & 7.8 & 27.6 \\
\hline Finland & 18.7 & 7.4 & 26.0 \\
\hline Germany & 16.9 & 6.7 & 23.6 \\
\hline Poland & 12.5 & 4.9 & 17.4 \\
\hline France & 9.8 & 3.8 & 13.6 \\
\hline Australia & 9.2 & 3.6 & 12.8 \\
\hline Japan & 7.1 & 2.8 & 10.0 \\
\hline South Africa & 6.4 & 2.5 & 8.9 \\
\hline Austria & 4.7 & 1.9 & 6.6 \\
\hline Norway & 3.4 & 1.3 & 4.8 \\
\hline Philippines & 1.5 & 0.6 & 2.2 \\
\hline $\begin{array}{l}\text { Republic } \\
\text { of Korea }\end{array}$ & 1.5 & 0.6 & 2.1 \\
\hline UK & 1.2 & 0.5 & 1.7 \\
\hline Thailand & 0.01 & 0.0 & 0.01 \\
\hline $\begin{array}{l}\text { Subtotal of } \\
\text { sample } \\
\text { countries }\end{array}$ & 513 & 202 & 715 \\
\hline
\end{tabular}

\section{BIOMASS WASTE MANAGEMENT}

The increasing production of agricultural biomass waste also poses risks to human health. Unregulated land disposal pollutes surface and ground waters, inducing eutrophication, and when incorporated into soil, biomass-induced microflora stimulate the production and emission of greenhouse gases (GHG) $\mathrm{NO}$ and $\mathrm{N}_{2} \mathrm{O}$, which have considerably greater global warming potential than $\mathrm{CO}_{2}{ }^{33}$

On a global scale, $>2 \mathrm{Gt}$ of crop residues are burned, ${ }^{34}$ contributing about $18 \%$ of total global emissions of $\mathrm{CO}_{2}$, plus significant quantities of particulates/black carbon. ${ }^{14,35}$ The use of biomass as fuel for cooking by the poorest households and agrarian communities is included, which comprises $38 \%$ of the global population. ${ }^{11,36}$

Notwithstanding, the complex environmental impacts, including the positive (e.g., biomass renewability and carbon neutrality) and negative (e.g., land use change, depletion of soil carbon and nutrient stocks and loss of biodiversity and water scarcity) implications, the use of biomass for energy production cannot be overlooked. ${ }^{37}$ The nature and scale of impacts depend on biomass type and extent of use. For example, open fires and lowefficiency stoves are traditionally used in developing countries, and result in poor indoor air quality. ${ }^{38}$

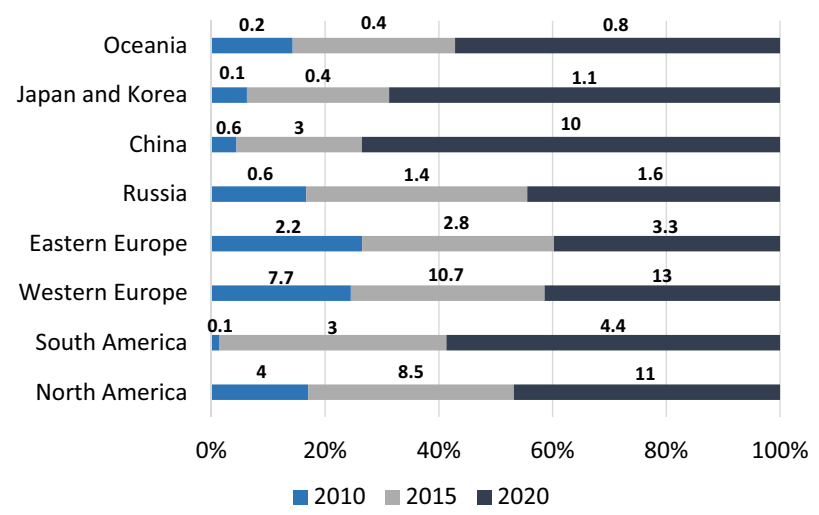

Fig. 3 Pellet production projections (from 2010 to 2020) for selected regions

As developing energy policy recognises the need to reduce coal use, renewable energy and the sustainable use of biomass resources is of increasing importance (IEA 2002-2003). ${ }^{39}$ Indeed, for a while in the summer of 2019, the UK did not burn coal, as alternative energy supplies met demand (https://www. theguardian.com/environment/2019/may/08/britain-passes-1week-without-coal-power-for-first-time-since-1882). ${ }^{40}$

As indicated, the major developments in the reuse of biomass residues over the past 25 years are primarily concentrated in the bioenergy sector, although use in specialist product development, alternative fuels and biochar production has also increased.

The use of agricultural residues for electric power/energy is widely reported. ${ }^{41-43}$ Renewable bioenergy includes crop-based biohydrogen production, e.g., from maize and sweet sorghum; herbaceous species, e.g., miscanthus, switchgrass and kenaf; from woody plants, e.g., eucalyptus. ${ }^{44}$ Although microbial-based biomass utilisation is also increasing, ${ }^{44}$ plant-based residues remain the primary interest for fuel feedstocks (e.g., cotton) ${ }^{45}$ and biochar production (utilising cotton husk, sugarcane filter cake, eucalyptus sawmill waste ${ }^{46}$ or miscanthus char). ${ }^{47}$ It is worth noting that biomass rich in lignin and carbohydrate has also been used to manufacture furan-based building blocks. ${ }^{48}$

In developed countries (including the OECD members), biomass waste is either lost/unused or re-utilised, e.g., for energy and heat production. ${ }^{30}$ In countries such as the USA, EU, Russia, Ukraine and Belarus, sawdust-based wood pellets are used as a source of energy and heat in domestic and industrial facilities. The European Biomass Association reported the consumption of $18.3 \mathrm{Mt}$ of pellets (or 79\% of global consumption) in the EU in 2013 with global use projected to increase from 22 to $50-80 \mathrm{Mt}$ by $2020 .^{49}$ PÖYRY ${ }^{50}$ predicts wood pellet production to 2020 (Fig. 3), with Schill et al. ${ }^{51}$ suggesting that global production will reach 77 Mt/p.a. by 2020.

In the USA, the bulk of the agricultural residues (140-350 Mt) is used by industry. Until recently, agricultural wastes were managed by burning or landfill, but now in many states (e.g., California, Washington and Oregon) this is prohibited. ${ }^{52,53}$ US agricultural residues, including corn stover (i.e., stalks and leaves) and wheat straw, comprise $155 \mathrm{Mt}$ of biomass, and have the potential for energy production. ${ }^{54,55}$

In Europe, straw is the main agricultural crop feedstock for bioenergy following a ban on field burning. ${ }^{56}$ The production of European straw residues is $340 \mathrm{Mt}$, and from cereal and oil crops it is $416 \mathrm{Mt}^{57}$ Denmark is the leader in utilising straw for energy production via district heating schemes $(3-5 \mathrm{~mW})$, industrial processing (1-2 mW) and domestic heating (10-100 kW). However, the impact of using straw for energy production has important implications for a reduction in the supply of organic matter to agricultural soils. ${ }^{56}$ 
The developing countries in Africa and Asia accounted for a $25 \%$ of global biomass waste use, with China comprising approximately $17 \% .^{57,58}$ This total exceeds the figure for industrialised countries (currently 3\%) due to traditional uses for these wastes..$^{59,60}$ However, as these countries including Brazil, China and India develop, it is likely that industrial applications for biomass waste will increase. In a number of African countries, the use of sugar bagasse to generate heat and electricity is increasing. ${ }^{61}$

Many countries do seek to avoid biomass waste disposal through resource recovery and utilisation, and we have seen the increased use of wood residues for energy generation. However, incineration and pyrolysis generate substantial amounts of ash that requires management. Countries such as China, Brazil, USA, Russia and France annually generate ash from wood utilisation of 0.061-0.24 Mt and from power production, 0.03-1.91 Mt. ${ }^{62}$ The world's largest biomass power station, DRAX, uses $7 \mathrm{Mt}$ of biomass waste p.a., which produces about 1.2 Mt of fly ash (FA) and around $0.24 \mathrm{Mt}$ of furnace bottom ash or FBA. ${ }^{63}$

Current utilisation of biomass for energy amounts to approximately $10 \%$ of global energy production, arising primarily from cooking and heating in the developing world. ${ }^{49,64}$ Manufactured wood pellets contribute to $<1 \%$ of the energy produced ${ }^{29,32}$ despite the EU and USA [the leaders in biomass-based power generation capacity] ${ }^{58}$ possessing a capacity of $1.2 \mathrm{Gt}$ of oil equivalent, which equates to $15 \%$ of the global energy consumption. ${ }^{65}$

\section{AN ALTERNATIVE APPROACH USING CAPTURED CARBON DIOXIDE AND UTILISATION}

Globally, the demand for 'carbon efficient' management solutions to conserve energy, minimise the $\mathrm{CO}_{2}$ emissions and utilise wastes is of increasing interest. The commitment of industrialised countries to reduce atmospheric $\mathrm{CO}_{2}$ emissions through carbon Capture and Storage initiatives is well known, but the ability to deliver is lacking due to cost and technology readiness. Recent technological developments have created opportunities for carbon dioxide utilisation (CCU), where $\mathrm{CO}_{2}$ is used as a feedstock that is transformed to produce a range of materials including construction materials, plastics and fuels. ${ }^{66}$ However, to keep costs low, the successful full deployment of CCU technology will be partially reliant upon the direct use of point emissions of $\mathrm{CO}$ and $\mathrm{CO}_{2}$, or where necessary, their preferential capture by using, e.g., low-cost sorbents, ${ }^{67}$ which may even be waste-derived. ${ }^{68}$

It should be noted that the intentional use of $\mathrm{CO}_{2}$ to condition cementitious materials has been practiced for decades, including for the rapid hardening of calcium silicate-based materials ${ }^{69}$ and concrete articles, such as roofing tiles. ${ }^{70}$ A carbonation step has been used to solidify cement-based wasteforms ${ }^{71,72}$ and to stabilise soil contaminated with a range of heavy metals including $\mathrm{Zn}, \mathrm{Cu}$ and $\mathrm{Pb}{ }^{73}$ Treatment of waste by carbonation to mitigate risk and to produce engineered materials suggests that the managed carbonation of biomass-derived wastes may be beneficial. Building on our previous endeavours, therefore, the carbonation of biomass ash is the primary focus of the present work.

The Gt quantities of biomass residues, generated yearly, are not managed sustainably. If biomass wastes have the potential for other uses and they do, their displacement should follow a 'waste management hierarchy', which recognises energy recovery, and disposal as the least favourable options. ${ }^{74}$ That said, the long-term use of sustainably produced biomass as a substitute feedstock for carbon-intensive products and fossil fuels, provides greater permanent reductions in atmospheric $\mathrm{CO}_{2}$ than preservation does.

The EU Waste Framework Directive requires action to minimise waste, reduce reliance on landfill and increase recycling. ${ }^{75}$ The US Department of Energy (DOE) and the US Department of
Agriculture (USDA) have mandated that $5 \%$ of heat and power energy, $20 \%$ of liquid transportation fuel and $25 \%$ of chemicals and materials should come from biomass by $2022 .^{76,77}$ The high potential of global biomass waste with respect to material and energy recovery is recognised, ${ }^{64}$ but the availability of novel technologies to effectively manage waste biomass remains wanting. This becomes more important when the wastes could be utilised to reduce the high pressure on the virgin material resources (e.g., soil and natural aggregates).

Our interest in $\mathrm{CO}_{2}$ is in the manufacture of value-added products utilising solid wastes. ${ }^{78,79}$ As solid wastes are already efficiently regulated and are managed in high volumes, they provide an obvious substrate for the 'mineralisation' of carbon. A summary of the current status is provided by the Global $\mathrm{CO}_{2}$ Initiative, ${ }^{80}$ and a case study concerning the production of construction materials is given by the UNEP GEO-6 Pan-European Assessment. ${ }^{81}$ Table 4 summarises waste streams that have the potential to be treated by carbonation technology, including biomass-derived waste ash.

The IEA projected that in 2030, both agricultural and forest residues will be increased globally to $6.8 \mathrm{Gt}$ (dry matter) from agriculture and $0.7 \mathrm{Gt}$ from forestry. ${ }^{60}$ Asia and North America are estimated to account for two-thirds of the available potential of biomass residue wastes from crop production. ${ }^{82}$ As developing countries, including India look for alternative material resources to meet their infrastructural growth needs and GHG reductions (www.bis.org.in/other/PR_NSNR.pdf), biomass wastes will increase in significance as potential resources.

The use of biomass residues in cement-bound composites comprising Portland cement, fly ash and blast furnace slag to manufacture building materials is practiced in several parts of the world. ${ }^{83-85}$ Plant fibres, such as flax shive, hemp and straw may be used; however, their durability is not guaranteed as these biological materials become denatured due to high $\mathrm{pH}$ and humidity environment in concrete products. Furthermore, the effects of lime crystallisation and the dissolution of cellulose, hemicellulose and certain lignins also contribute to denaturing of these additives. ${ }^{86-89}$ The surface of fibre-based construction materials is also prone to degradation by fungal growth, which in turn, adversely impacts indoor air quality. ${ }^{89}$

The use of a low-carbon engineering approach to biomass wastes including their ashes can involve captured gaseous $\mathrm{CO}_{2}$ to produce construction materials. The products have potential to be significantly carbon negative in a 'closed loop' manufacturing process. In utilising $\mathrm{CO}_{2}$ directly from point sources and locking it up in the built environment, high volumes of waste and $\mathrm{CO}_{2}$ could be stored in manufactured products as mineral carbonates. Described by Bertos et al., $^{78}$ the production of manufactured carbonated aggregates for use in blocks/bricks is established $^{80,81,90}$ with these products being commercially available (www.c8s.co.uk, www.c8a.co.uk). Table 4 lists industrial waste streams with potential to be used as feedstock with gasesous carbon dioxide in the manufacture of low-carbon materials.

\section{POTENTIAL BENEFITS}

The biomass ashes, derived from fruit peel, crop fibre, nut shells and wood waste, are often reactive to $\mathrm{CO}_{2}$ and can be valorised via a managed carbonation step as construction products. The ash generated from biomass-based power plants can be combined with the point-source $\mathrm{CO}_{2}$ captured directly from the incineration process into sustainable, carbon-negative construction materials.

Waste to energy plants emits $47 \mathrm{Mt} \mathrm{CO}_{2}$ each year, ${ }^{58}$ and as the ashes generated tend to be reactive to $\mathrm{CO}_{2}$ to a lesser or greater degree, there is potential to mineralise these ashes to manufacture value-added products.

In Europe, biomass waste arising from straw and other cereal and oil crops is projected to be $756 \mathrm{Mt}$ by $2030 .^{56}$ As such, a 
Table 4. Overview of waste streams with potential for CCU

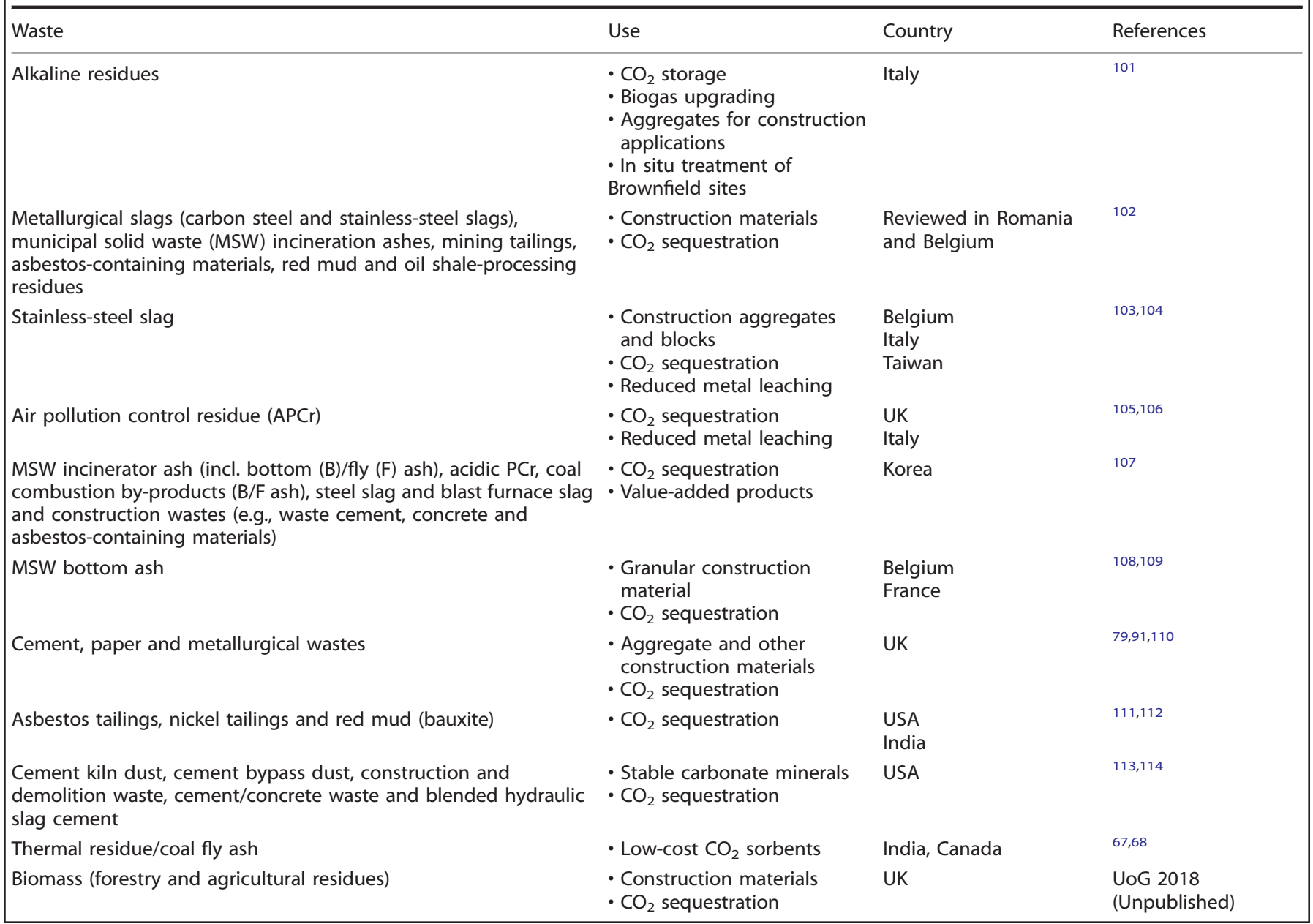

considerable resource exists that has potential to be utilised. The environmental and economic perspectives of the biomass utilisation, by using a CCU approach as described, are given in Fig. 4.

The on-site, i.e., from stack $\mathrm{CO}_{2}$ capture opportunity offered by waste carbonation, provides a robust 'closing of the process loop' option to offset anthropogenic point-source $\mathrm{CO}_{2}$ emissions. ${ }^{91}$ However, from a developing country perspective, where virgin materials use predominates, the use of biomass waste-based products could be attractive as a supplementary sustainable material supply. For example, India has $141 \mathrm{M}$ ha of arable land producing $\sim 800 \mathrm{Mt} / \mathrm{p}$.a. of agricultural/horticultural products. The 500-550 Mt/p.a. of surplus residues include ashes arising from burning on farms (90-140 Mt/p.a.). ${ }^{35,92}$

In Europe, 276 Mt/p.a. of cereal and oil crop residues are produced. ${ }^{57}$ This considerable potential resource informed our study of different plant-based biomass residues, including wood, nut shell, fibre and soft (fruit and vegetable) peel. The ashes arising were analysed, and their potential to react with $\mathrm{CO}_{2}$ gas was assessed (Table 5). As can be seen, the different ashes combine with significant amounts of mineralised $\mathrm{CO}_{2}$. The results reflect the difference in chemistry and mineralogy of the ashes.

The biomass residues studied in this work were sourced in India, Africa and the UK. They were combusted in a Muffle furnace at $800 \pm 25^{\circ} \mathrm{C}$ with a residence time of $4 \mathrm{~h}$. The resulting ashes were then examined for selected physical properties (e.g., particle size, bulk density, surface area and ash content) and their chemical (total carbon, elemental and phase chemistry) composition. The biomass ashes were tested for their reactivity to pure $\mathrm{CO}_{2}$ at $20 \%$ moisture $(\mathrm{w} / \mathrm{w})$ and a pressure of $\sim 2$ bar. The ashes were exposed to $\mathrm{CO}_{2}$ for four-separate cycles in a closed pressurised carbonation chamber, with the first three cycles extending to $1 \mathrm{~h}$ each, and the fourth cycle being $24 \mathrm{~h}$. The uptake of $\mathrm{CO}_{2}$ by ashes was determined on weight gain ( $\% \mathrm{w} / \mathrm{w}$ ) basis and correlated against the results obtained from analysis by X-ray diffractometry with Reitveld refinement. The dry-carbonation method employed has been directly correlated with the $\mathrm{CO}_{2}$ uptake achieved in commercial carbonation facilities operating in the UK.

\section{Preparation and characterisation of products from biomass}

The pure biomass ashes were combined with $10 \%$ moisture $(\mathrm{w} / \mathrm{w})$ and then pressed into small cylindrical monolithic samples $(7 \times$ $7 \mathrm{~mm}$ ). Five monoliths were cast for each ash and then exposed to pure $\mathrm{CO}_{2}$ for $24 \mathrm{~h}$. The $\mathrm{CO}_{2}$ uptake by the monoliths was calculated on weight gain (w/w \%) basis and also by $\mathrm{CHN}$ analysis. The strength of these monolithic products is a reflection of how well carbonate-cemented they are. Compressive strength was obtained by applying a force until the cylinders failed by using Eq. (1)

$\sigma_{c}=\frac{2.8 F_{c}}{\pi d m^{2}}$

where $\sigma_{c}$ is the compressive strength in megapascals (MPa), $F_{c}$ is the fracture load in kilonewtons $(\mathrm{kN}), A m$ is the mean area of the cylinder and $d m$ is the mean diameter of the cylinder. 
Biomass residue burning/landfilling

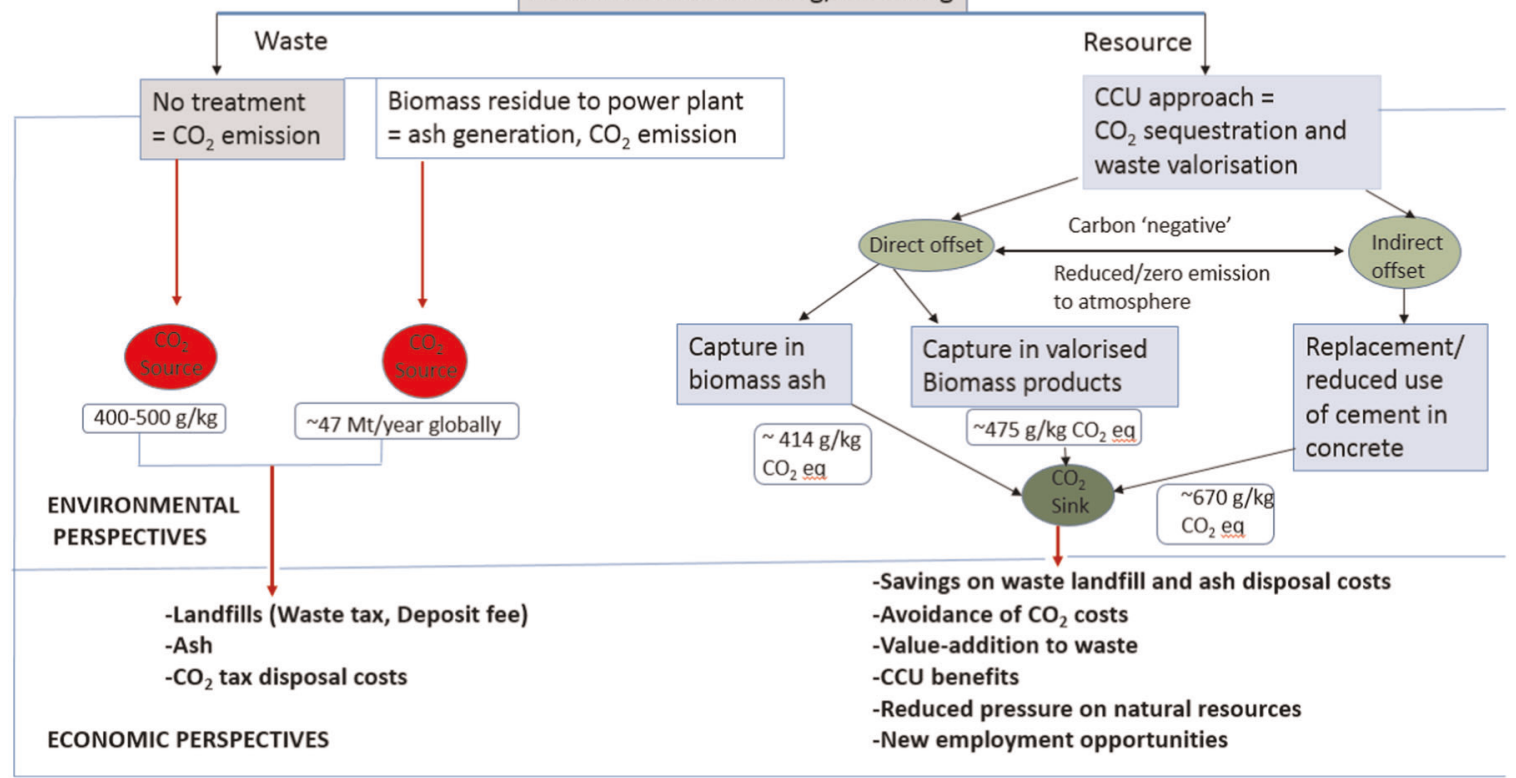

Fig. 4 Environmental and economic perspectives of biomass waste valorisation by using a CCU-based approach

The water resistance of carbonated 'ash only' monoliths can be used as a measure of moisture senstitivity, and was monitored by immersing them into water for 30 days.

It was found that most of the wood biomass, nut shell, fibres and soft peel had significant potential to uptake $\mathrm{CO}_{2}$ into their ashes at up to $414 \mathrm{~g} / \mathrm{kg}$. When fabricated into small monolithic cylindrical products, the $\mathrm{CO}_{2}$ uptaken was slightly higher, at up to $475 \mathrm{~g} / \mathrm{kg}$ product (Fig. 4), due to greater exposure to $\mathrm{CO}_{2}$ gas.

With the exception of some poorly- or non-reactive ashes, the strength of the cylindrical monolithic products exceeded the criteria given in the European standard for light-weight aggregates (Table 5), which is $1200 \mathrm{~kg} / \mathrm{m}^{3} .{ }^{93}$ Incidentally, this is also the strength requirement sufficient for 'End of Waste' approval for manufactured carbonated aggregates made from other thermal residues. $^{94}$ This part of our work has been submitted for publishing as a case study.

From our laboratory studies with a range of biomass wastes, we can reasonably assume that $70 \%$ of these biomass wastes produce $\mathrm{CO}_{2}$-reactive ashes. If the average ash content is $5 \%(\mathrm{w} / \mathrm{w}$ dry weight) of that burned, and the $\mathrm{CO}_{2}$ mineralised is of the order of $10 \%(\mathrm{w} / \mathrm{w})$ as observed, there is potential to mineralise about 1.0 $\mathrm{Mt}$ of $\mathrm{CO}_{2}$ in approximately $10 \mathrm{Mt}$ ash produced in Europe. Furthermore, our work indicates that these reactive ashes could be used to carbonate-cement the remaining $30 \% \mathrm{w} / \mathrm{w}$ of 'raw' biomass residues (utilising some $83 \mathrm{Mt}$ arising from cereal and oil crops). The ash/raw biomass ratio of 1:8 (or approximately $12 \% \mathrm{w} /$ w) was typically high enough to produce a potentially useful monolithic composite product. The indication that biomass ashes can be directly used to cement 'raw' biomass into a hardened composite product has not been explored elsewhere. The original findings of this particular work have been communicated separately.

The available residues from European cereal and oil crops are projected to rise to $340 \mathrm{Mt}$ by 2030 . Their ashed residues have potential to mineralise $1.2 \mathrm{MtCO}_{2}$ directly, or via the production of carbonate-cement manufactured valorised products. On a global scale, the projections for 2050 indicate an increase in demand for all biomass wastes, with a larger proportion of agricultural residues being used for energy production. ${ }^{15,95}$
Table 5. $\mathrm{CO}_{2}$ uptake potential in biomass ashes and strength of monolithic products

\begin{tabular}{lll}
\hline Biomass ashes & $\begin{array}{l}\mathrm{CO}_{2} \text { uptake } \\
(\% \mathrm{w} / \mathrm{w})\end{array}$ & $\begin{array}{l}\text { Monolithic product } \\
\text { strength }(\mathrm{MPa})\end{array}$ \\
\hline $\begin{array}{l}\text { Wood shavings and } \\
\text { saw dusts }\end{array}$ & $18.6-41.4$ & $0.122-0.491$ \\
Nut shell & $9.9-15.6$ & $0.169-0.183$ \\
Soft peel & $4.86-29.5$ & $0.041-0.313$ \\
Fibres & $5.6-24.2$ & $0.047-0.161$ \\
\hline
\end{tabular}

Biomass fibres are used for making light-weight concretes ${ }^{96}$ bound by Portland cement and lime-based binders, which are directly associated with $\mathrm{CO}_{2}$ emissions [e.g., arising primarily from the 'cooler' end of the cement kiln, which operates at $600-900^{\circ} \mathrm{C}$ ]. As our work has shown that biomass ash can be used as a substitute for hydraulic cement, or be used as a carbonateable medium in its own right, there are important implications for the use of ash in bound products. Not least, the cold-processing route described has a low-energy intensity, which is unlike that of the firing, sintering or bloating processes employed in the production of bricks or manufactured aggregates.

As biomass ashes can be used to replace hydraulic cement to produce carbonated biomass-based construction materials, there is significant potential to 'offset' carbon. With reference to Fig. 4, and the offsetting of $\mathrm{CO}_{2}$ from cement production, we assume that for some applications selected, biomass ash additions can help to promote a reduction of $10 \%$ use in Portland cement. For clarity, we are not concerned with the ability of ashes to act as a pozzolan, but as a ready source of $\mathrm{CaO}$ that can form calcium silicate hydrate. If the ashes contain reactive silica, which some do, then there are further possible advantages in terms of strength and durability. Either way-whether an addition to a hydraulicallyor a carbonate-bound system, the careful use of selected ashes could significantly lower the embodied carbon of construction materials employing a blended PC-biomass ash binder.

The available crop residues on a global scale are considerable as a number of modelling studies suggest that those currently 
available from agriculture (including for energy) are $2.9 \mathrm{Gt} / \mathrm{p} .{ }^{95,96}$ Table 6 gives a high-level view of the potential of biomass residues to generate ash that is able to be reacted with $\mathrm{CO}_{2}$.

With the approach as described, biomass waste dumping could be reduced, and the impacts of leaching of hazardous chemicals/ contaminants into surface and groundwater, and the associated health impacts mitigated. ${ }^{97}$ The costs of these bio-waste-based products could be higher in countries where the gate fees for landfill are relatively low or not mandatory-thereby encouraging reuse rather than disposal. In the United States, landfill fees can be relatively low (US $\$ 44 / \mathrm{t}$ ), and this may be behind why $54 \%$ of biomass wastes went to landfill (2011). Countries paying higher landfill gate fees and for the waste to energy already have an incentive to valorise waste otherwise destined for final disposal. For instance, the tipping fees in the UK for wood waste is up to $£ 82 / t$ (2016 figure) ${ }^{98}$ excluding landfill tax and transport.

\section{IMPLICATIONS}

The utilisation of biomass wastes through their combination with mineralised $\mathrm{CO}_{2}$ could help close the process 'loop' and reduce the adverse environmental impacts arising from waste.

As biomass residues are increasingly burnt in power plants to produce energy, it has been shown that their ashes and pointsource $\mathrm{CO}_{2}$ can be combined in the manufacture of carbonated products. This circular management strategy has potential to preserve landfill space, increase the resources available for construction and reduce $\mathrm{CO}_{2}$ emissions, and environmental harms.

As not all biomass ash residues are suitable for direct processing by carbonation, our experience is that many are readily carbonateable due to their facilitating mineral content. In this case, those that are not $\mathrm{CO}_{2}$-reactive can be used in their 'raw' forms in combination with reactive biomass ashes to produce composite products. Therefore, by the careful mixing of biomass ashes and raw wastes, carbonate-cemented composite products can be manufactured; findings will be reported fully elsewhere.

In developing countries where biomass residues are available in quantity, ${ }^{99}$ and development goals are driving rapid urbanisation, new products with potential to replace virgin materials may have wide benefits.

\section{DATA AVAILABILITY}

The data that support the findings of this study are available from the corresponding authors upon reasonable request. Subject to IP considerations, this ongoing work develops a database that will be developed and made available.

Received: 16 January 2019; Accepted: 12 August 2019; Published online: 14 October 2019

\section{REFERENCES}

1. UNEP (United Nations Environment Programme) Converting waste agricultural biomass into a resource. United Nations Environment Programme Division of Technology, Industry and Economics International Environmental Technology Centre, Osaka/Shiga, Japan. www.unep.org/ietc/Portals/136/Publications/Waste \%20Management/WasteAgriculturalBiomassEST_Compendium.pdf (2015).

2. Chun, A. M. S. Ground Rules for Humanitarian Design (eds Chun, A. M. S. \& Brisson, E.) (Wiley Publishers, London, 2015) ISBN 978-1-118-36159-7.

3. FAO. Global forest products facts and figures. Available at: http://www.fao.org/ fileadmin/user_upload/newsroom/docs/2011\%20GFP\%20Facts\%20and\% 20Figures.pdf (2011).

4. Schieber, A., Stintzing, F. C. \& Carle, R. By-products of plant food processing as a source of functional compounds-Recent developments. Trends Food Sci. Technol. 12, 401-413 (2001).

5. Yevich, R. \& Logan, J. An assessment of biofuel use and burning of agricultural waste in the developing world. Glob. Biogeochem. Cycles 17, 1095 (2003). 
6. Khedari, J., Charoemvai, S. \& Hiruanlabh, J. New insulating particle boards from durian peel and coconut coir. J. Build. Environ. 38, 435-441 (2003).

7. UNEP. Global Partnership on Waste Management. http://web.unep.org/gpwm/ what-we-do/waste-agricultural-biomass

8. Nakamura, T. Waste Agriculture Biomass Convention, the 6th Biomass Asia Workshop in Hiroshima, 18-20 November 2009, IETC Osaka. http://www. biomass-asia-workshop.jp/biomassws/06workshop/presentation/25_Nakamura. pdf. New York Times dates 5 August 2010, New York (2009).

9. Centore, M., Hochman, G. \& Zilberman, D. Worldwide survey of biodegradable feedstocks, waste-to-energy technologies, and adoption technologies. Modelling, Dynamics, Optimization and Bioeconomics I. A. A. Pinto and D. Zilberman (eds.). Springer Proceedings in Mathematics and Statistics 73, https://doi.org/ 10.1007/978-3-319-04849-9_11 (2014).

10. Smil, V. Nitrogen in crop production. Glob. Biochem. Cycles 13, 647-662 (1999).

11. IEA, International Energy Agency, CCC World forest and agricultural crop residue resources for co-firing. ISBN 978-92-9029-571-6. https://www.usea.org/sites/ default/files/042015_World\%20Forest\%20and\%20agricultural\%20crop\% 20residue\%20resources\%20for\%20cofiring_ccc249.pdf (2015).

12. Hiloidhari, M., Das, D. \& Baruah, D. C. Bioenergy potential from crop residue biomass in India. Renew. Sustain. Energy Rev. 32, 504-512 (2014).

13. Jiang, D., Zhuang, D., Fu, J., Huang, Y. \& Wen, K. Bioenergy potential from crop residues in China: availability and distribution. Renew. Sustain. Energy Rev. 16, 1377-1382 (2012).

14. FAO World agriculture: towards 2015/2030. Summary Report ISBN 92-5-1047618 http://www.fao.org/3/a-y3557e.pdf and http://www.fao.org/docrep/004/ y3557e/y3557e04.htm\#TopOfPage (2002).

15. Slade, R., Saunders, R., Gross, R. \& Bauen, A. Energy from biomass: the size of the global resource. An assessment of the evidence that biomass can make a major contribution to future global energy supply. Imperial College Centre for Energy Policy and Technology and UK Energy Research Centre, London. ISBN: 1903144 108 (2012).

16. FAO. The State of Food Insecurity in the World. Economic growth is necessary but not sufficient to accelerate reduction of hunger and malnutrition. World Food Programme (WFP) \& International Fund for Agricultural Development (IFAD) (2012)

17. Bentsen, N. S., Felby, C. \& Thorsen, B. J. Agricultural residue production and potentials for energy and materials services. Prog. Energy Combust. Sci. 40, 59-73 (2014).

18. FAO. World Agriculture Towards 2030/2050: The 2012 revision ESA E Working Paper No. 12-03. http://www.fao.org/fileadmin/user_upload/esag/docs/ AT2050_revision_summary.pdf (2012).

19. FAO. Global agriculture towards 2050. High Level Expert Forum - How to Feed the World in 2050. www.fao.org/fileadmin/templates/wsfs/docs/lssues_papers/ HLEF 2050_Global_Agriculture.pdf (2009).

20. FAO. World agriculture: towards 2015/2030 An FAO Perspective. (Earthscan, London), 2003. http://www.fao.org/3/a-y4252e.pdf.

21. FAO. Trade and Markets Division Food Outlook May 2015. Oil crops. http://www. fao.org/fileadmin/templates/est/COMM_MARKETS_MONITORING/Oilcrops/ Documents/Food_outlook_oilseeds/FO_May_2015.pdf (2015).

22. Koerbitz, W. Biodiesel production in Europe and North America: an encouraging prospect. Renew. Energy 16, 1078-1083 (1999).

23. Raneses, A., Glaser, L., Price, J. \& Duffield, J. Potential biodiesel markets and their economic effects on the agricultural sector of the United States. Ind. Crops Products 9, 151-162 (1999).

24. EPRS. European Parliamentary Research Service. Members' Research Service PE 568.329 (2015)

25. FAOSTAT. Available at www.faostat.fao.org and http://faostat.fao.org/faostat (2013).

26. PBL Netherlands Environmental Assessment Agency Report. Integrated analysis of global biomass flows in search of the sustainable potential for bioenergy production. PBL Publication no. 1509. http://www.pbl.nl/sites/default/files/cms/ publicaties/pbl-2014-integrated-analysis-of-global-biomass-flows-in-search-ofthe-sustainable-potential-for-bioenergy-production-1509.pdf (2014).

27. FAO Regional Study on Wood Energy Today and Tomorrow in Asia. Asia-Pacific Forestry Sector Outlook Study: Paper No: APFSOS/WP/34, Food and Agricultural Organization of the United Nations Forestry Policy and Planning Division, Rome, Italy. http://www.fao.org/docrep/w7744e/w7744e00.htm\#Contents (1997).

28. FAO. www.fao.org/docrep/006/AD576E/ad576e00.pdf (2013).

29. FAO. Global forest resources assessment. FAO Forestry Paper 163. Food and Agricultural Organization of the United Nations, Rome, Italy; 378 pp (2010).

30. IEA, International Energy Agency, Global Wood Pellet Industry Market and Trade Study. IEA Task 40 (2012).

31. UNEP, Technologies for Converting Waste Agricultural Biomass to Energy. Reading material. http://www.mag.go.cr/proyectos/proy-residuos-agricolas-org/
materiales/Tecnologies\%20for\%20convertin\%20wab\%20to\%20energy.pdf (2013).

32. IEA CCC, Author's analysis. IEA Clean Coal Centre, London, UK (2014).

33. Koch, W. Landfill Projects on the rise. https://usatoday30.usatoday.com/money/ industries/energy/2010-02-24-landfill-energy_N.htm (2010).

34. Devi, S., Gupta, C., Jat, S. L. \& Parmar, M. S. Crop residue recycling for economic and environmental sustainability: The case of India. Open Agriculture 2, 486-494 (2017).

35. Jain, N., Pathak, H. \& Bhatia, A. Sustainable management of crop residues in India. Current Advances in Agricultural Sciences, 6(1) 1-9, ISSN: 0975-2315 (2014).

36. IEA. https://www.iea.org/media/weowebsite/WEO2016Biomassdatabase.xlsx (2016).

37. World Energy Council, World Energy Resources: Bioenergy. https://www. worldenergy.org/wp-content/uploads/2013/10/WER20137Bioenergy.pdf (2013).

38. Chum, H. et al. Bioenergy. In: (eds Edenhofer, O. et al.) IPCC Special Report on Renewable Energy Sources and Climate Change Mitigation. (Cambridge University Press, Cambridge, United Kingdom and New York, NY, USA, 2011).

39. IEA. Sustainable Production of Woody Biomass for Energy A Position Paper Prepared by IEA Bioenergy. ExCo 2002:03, https://www.ieabioenergy.com/wp-content/uploads/ 2013/10/25_PositionPaper-SustainableProductionofWoodyBiomassforEnergy.pdf

40. Ogden, C. UK's longest ever coal-free run comes to an end. Env. J. https:// environmentjournal.online/articles/uks-longest-ever-coal-free-run-comes-to-anend/ (2019).

41. Ergüdenler, A. \& Işiğigür, A. Agricultural residues as a potential resource for environmentally sustainable electric power generation in Turkey. Renew. Energy 5, 786-790 (1994).

42. Paula, L. E. de R.e, Trugilho, P. F., Napoli, A., Bianchi, M. L. Characterization of residues from plant biomass for use in energy generation. CERNE, 17, 237-246 (2011).

43. Miles, T. R. Sr. \& Miles, T. R. Jr. Environmental implications of increased biomass energy use. National Renewable Energy Laboratory (NERL) Report. NREL\{fP-2304633 UC Category: 247, DE92001219 (1992).

44. Saratale, G. D., Saratale, R. G., Banu, J. R. \& Chang, J. S. Biohydrogen production from renewable biomass resources. Biohydrogen (second edition). Biomass Biofuels Biochem. 247-277, https://doi.org/10.1016/B978-0-444-64203-5.00010-1 (2019).

45. Sumner, H. R., Hellwig, R. E. \& Monroe, G. E. AGRIS 27, 968-972 (1985).

46. Speratti, A. B., Johnson, M. S., Sousa, H. M., Dalmagro, H. J. \& Couto, E. G. Biochars from local agricultural waste residues contribute to soil quality and plant growth in a Cerrado region (Brazil). Arenosol 10, 272-286 (2018).

47. Kwapinski, W. et al. Biochar from biomass and waste. Waste Biomass Valorisation https://doi.org/10.1007/s12649-010-9024-8 (2010).

48. Jong, E. de \& Gosselink, R. J. A. Lignocellulose-based chemical products. Bioenergy Res. 277-313, https://doi.org/10.1016/B978-0-444-59561-4.00017-6 (2014).

49. EPRS, European Parliamentary Research Service. Members' Research Service PE 568.329 (2015)

50. PÖYRY. Wood Pellets: Global Market, Players and Trade to 2015-Marketing Newsletter (2009).

51. Schill, S. R. Global Pellet Market to Reach \$9 Billion by 2020. Biomass Magazine. Available at: http://biomassmagazine.com/articles/10194/global-pellet-marketto-reach-9-billion-by-2020 (2014).

52. Hayes, M. Agricultural Residues: A Promising Alternative to Virgin Wood Fiber (1997). Retrieved from: http://www.woodconsumption.org/alts/meghanhayes. html.

53. Guangnan, Y., Kimmy, P. \& Daniel, K. An Investigation into $30 \%$ Post-Consumer Recycled Wood Fiber Paper and Wheat Paper. UBC Social Ecological Economic Development Studies (SEEDS) Student Report, APSC, University of British Columbia, 262 (2012).

54. Concerned Scientists, Biomass Resources in the United States. http://www. ucsusa.org/clean-vehicles/better-biofuels/biomass-energy-resources\#.Voo3WJ ggmUk (2012)

55. Blue Economy. Straw-the Next Eco-Innovative Pacesetter (2015).

56. Kretschmer, B., Allen, B. \& Hart, K. Mobilising Cereal Straw in the EU to feed Advanced Biofuel Production. Report produced for Novozymes. (IEEP, London, 2012).

57. ICCT. Availability of Cellulosic Residues and Wastes in the EU. White Paper, International Council on Clean Transportation. Washington (2013). http://theicct. org/sites/default/files/publications/ICCT_EUcellulosic-waste-residues_20131022. pdf

58. EU Regulation. http://eur-lex.europa.eu/LexUriServ/LexUriServ.do?uri=OJ:L:2013:347: 0608:0670:EN:PDF.

59. ECN, SNV (Netherlands Development Organisation), Biomass Waste-to-Energy Toolkit for Development Practitioners, SNV, the Netherlands. https://pdfs. 
semanticscholar.org/1d24/3523c945dbef393524932c08ddc6839b48c9.pdf (2014). Accessed 28 Dec 2018.

60. IEA, International Energy Agency, Sustainable Production of SECOND -Generation Biofuels Potential and perspectives in major economies and developing countries. https://www.iea.org/publications/freepublications/publication/secon dgenerationbiofuels.pdf (2010).

61. REN21, Renewables 213-Global Status Report. Available at: http://www.ren21. net/REN21Activities/GlobalStatusReport.aspx (2013).

62. James, A. K., Thring, R. W., Helle, S. \& Ghuman, H. S. Ash management reviewapplications of biomass bottom ash. Energies 5, 3856-3873 (2012).

63. Ashtrans Europe. STEAG Power Minerals and ZAG International, a World Perspective and New Trends http://ashtrans.eu/onewebmedia/4\%20\%20\%20\% 20Steag\%20Power\%20Minerals\%20Ashtrans\%202014\%20-\%20Berlin.pdf (2014).

64. UNEP, Converting Waste Agricultural Biomass into a Resource. UNEP Compendium of Technologies. http://www.unep.org/ietc/Portals/136/Publications/Waste \%20Management/WasteAgriculturalBiomassEST Compendium.pdf (2009).

65. ABC Hansen. Wood Waste Briquetting Plant, Denmark: ABC Hansen A/S (2001)

66. Armstrong, K. and Styring, P. Assessing the potential of utilization and storage strategies for post-combustion $\mathrm{CO}_{2}$ emissions reduction. Front. Energy Res. https://doi.org/10.3389/fenrg.2015.00008 (2015)

67. Kaithwas, A., Prasad, M., Kulshreshtha, A. \& Verma, S. Industrial wastes derived solid adsorbents for $\mathrm{CO}_{2}$ capture: a mini review. Chem. Eng. Res. Des. 90, 1632-1641 (2012).

68. Belmabkhout, Y., Serna-Guerrerom, R. \& Sayari, A. Adsorption of $\mathrm{CO}_{2}$-containing gas mixtures over amine-bearing pore-expanded MCM-41 silica application for $\mathrm{CO}_{2}$ separation. Adsorption 17, 395-401 (2011).

69. Berger, R. L., Young, J. F. \& Leung, K. Acceleration of hydration of calcium silicates by carbon dioxide treatment. Nat. Phys. Sci. 240, 16-18 (1972).

70. Maries, A. \& Hills, C. D. Improvement in concrete articles. UK Patent 2, 192, 392 (1986).

71. Lange, L. C., Hills, C. D. \& Poole, A. B. Preliminary investigation into the effects of carbonation on cement-solidified hazardous wastes. Environ. Sci. Technol. 30, 25-30 (1996).

72. Lange, L. C., Hills, C. D. \& Poole, A. B. The effect of carbonation on the properties of blended and non-blended cement solidified waste forms. J. Hazard. Mater. 52, 193-212 (1997).

73. Whitehead, K., Hills, C. D., MacLeod, C. L., \& Carey P. J. A Field Application of ACT for the Remediation of an ex-Pyrotechnics Site: Monitoring Data and Microstructural Studies, WASCON 2003, Proc. 5th International Conference on the Environmental and Technical Implications of Construction with Alternative Materials, San Sebastian, Spain, 4th-6th June, 2003 (2003)

74. UNEP. Resource Efficiency: Economics and Outlook for Asia and the Pacific. (CSIRO Publishing, Canberra, 2011).

75. Searle S. \& Malins, C. Availability of cellulosic residues and wastes in the EU. White Paper, The International Council on Clean Transportation. http://theicct. org/sites/default/files/publications/ICCT_EUcellulosic-waste-residues_20131022. pdf (2013).

76. Perlack, R. D. et al. Biomass as Feedstock for a Bioenergy and Bio-products Industry: The Technical Feasibility of a Billion-Ton Annual Supply, U.S. Department of Energy \& U.S. Department of Agriculture, Oak Ridge, Tenn, USA (2005).

77. Balan,V. Current Challenges in Commercially Producing Biofuels from Lignocellulosic Biomass. ISRN Biotechnology. Volume 2014 Article ID 463074, 31 http://www.hindawi.com/journals/isrn/2014/463074/ (2014).

78. Fernández Bertos, M., Simons, S. J. R., Hills, C. D. \& Carey, P. J. A review of accelerated carbonation technology in the treatment of cement-based materials and sequestration of $\mathrm{CO}_{2}$. J. Hazard. Mater. B112, 193-205 (2004).

79. Gunning, P. J., Hills, C. D. \& Carey, P. J. Accelerated carbonation treatment of industrial wastes. Waste Manag. 30, 1081-1090 (2010).

80. $\mathrm{GCl}$, Global $\mathrm{CO}_{2}$ Initiative, Global Roadmap for Implementing $\mathrm{CO}_{2}$ Utilisation, November (2016). https://www.globalco2initiative.org.

81. UNEP/UNECE. GEO-6 Assessment for the pan-European region. United Nations Environment Programme, Nairobi, Kenya (2016).

82. Rose, S. et al. Bioenergy in energy transformation and climate management. Climatic Change 123, 477-493 (2014).

83. Amziane, S., Arnaud, L. (Ed.), Bio-aggregate-based Building Materials: Applications to Hemp Concretes. (ISTE Ltd. and John Wiley \& Sons, 2013).

84. Chevanan, N. et al. Bulk density and compaction behaviour of knife mill chopped switchgrass, wheat straw, and corn stover. Bior Tech. 101, 207-214 (2010).

85. Sonebi, M. Rheological Properties of grouts with viscosity modifying agents as diutan gum and welan gum incorporating pulverised fly ash. Cem. Concr. Res. 36, 1609-1618 (2006).

86. Gueguen, M., Moscardelli, S., Van Schoors, L., Nour, I. \& Marceau, S. Study of the microbial development impact on bio-based materials. In (eds Amziane, S. \&
Sonebi, M.) Proc 1st Int Conf on Bio-Based Build Mater, (RILEM Publications s.a.r. I., Clermont-Ferrand, France, 2015) 166-169.

87. Sonebi, M., Wana, M., Amziane, S. \& Khatib, J. Investigation of the mechanical performance and weathering of hemp concrete. In (eds Amziane, S. \& Sonebi, M.) Proc 1st Int Conf on Bio-Based Build Mater. (RILEM Publications s.a.r.l., Clermont-Ferrand, France, 2015) 416-421.

88. Castel, Y., Amziane, S. \& Sonebi, M. Durabilite du beton de chanvre: resistance aux cycles d'immersion hydrique et sechage, lère Con- férence EuroMaghrébine des BioComposites, 28-31 March 2016, Marrakech (2016).

89. Filho, R. D., Toledo, F., de Andrade Silva, E. M. R., Fairbairn, J. \& Filho de, A. M. Durability of compression molded sisal fiber reinforced mortar laminates. Constr. Build Mater. 23, 2409-2420 (2009).

90. CO2Chem. carbon Dioxide Utilisation network www.co2chem.co.uk (2017).

91. Gunning, P. J., Hills, C. D. \& Carey, P. J. Production of lightweight aggregate from industrial waste and carbon dioxide. Waste Manag. 29, 2722-2728 (2009).

92. NAAS. Management of Crop Residues in the Context of Conservation Agriculture. Policy Paper No. 58, National Academy of Agricultural Sciences, New Delhi 12 p. (2012)

93. BSEN (2016).

94. Gunning, P. J., Antemir, A., Hills, C. D. \& Carey, P. J. Secondary aggregate from waste treated with carbon dioxide. Proc. Inst. Civ. Engineers 164, 231-239 (2011).

95. Baruya, P. World forest and agricultural crop residue resources for co-firing. IEACCC, CCC/249. ISBN: 978-92-9029-571-6 (2015).

96. Amziane, S. \& Sonebi, M. Overview on bio-based building material made with plant aggregate. Rilem Tech. Lett. 1, 31-38 (2016).

97. FAO. Water pollution from agriculture: a global review. Food and Agriculture Organization of the United Nations Rome, and the International Water Management Institute on behalf of the Water Land and Ecosystems research program Colombo (2017).

98. WRAP. Comparing the cost of alternative waste treatment options-Gate Fees report. http://www.wrap.org.uk/content/cpmparing-cost-alternative-waste-treatmentoptions-gate-fees-report-2016 (2016).

99. Tripathi, N., Hills, C. D., Singh, R. S. \& Carey, P. J. Construction: use waste for building. Nature 550, 457 (2017).

100. Bentsen, N. S. \& Felby, C. Technical potentials of biomass for energy services from current agriculture and forestry in selected countries in Europe, The Americas and Asia. Forest \& Landscape Working Papers No. 54, 31 pp. Forest \& Landscape Denmark, Frederiksberg (2010).

101. Baciocchi, R., Costa, G., Polettini, A., Pomi, R. \& Stramazzo, A. Accelerated carbonation of steel slags using $\mathrm{CO}_{2}$ diluted sources: $\mathrm{CO}_{2}$ uptakes and energy requirements. 5th International Conference on Accelerated Carbonation for Environmental and Material Engineering (ACEME) (2015).

102. Bodor, M., Santos, R. M., van Gerven, T. \& Vlad, M. Recent developments and perspectives on the treatment of industrial wastes by mineral carbonation - a review. Cent. Eur. J. Eng. 3, 566-584 (2013).

103. Salman, M. et al. Effect of accelerated carbonation on AOD stainless steel slag for its valorisation as a $\mathrm{CO}_{2}$-sequestering construction material. Chemical Engineering Journal, https://doi.org/10.1016/j.cej.2014.02.051 (2014).

104. Chang, E. E., Pan, S. Y., Chen, Y. H., Chu, H. W. \& Chiang, P. C. $\mathrm{CO}_{2}$ sequestration by carbonation of steelmaking slags in an autoclave reactor. J. Hazard. Mater. 195, 107-114 (2011).

105. Alfieria, F., Gunning P. J., Galloc, M., Borghid, A. D. \& Hills, C. D. Monitoring of carbon dioxide uptake in accelerated carbonation processes applied to air pollution control residues. Proceedings of ECOS 2012-the 25th international conference on efficiency, cost, optimization, simulation and environmental impact of energy systems, June 26-29, 2012, Perugia, Italy (2012).

106. Cappai, G., Cara, S., Muntoni, A. \& Piredda, M. Application of accelerated carbonation on MSW combustion APC residues for metal immobilization and CO2 sequestration. J. Hazard. Mater. 207-208, 159-164 (2012).

107. Cho, J. S., Kim, S. M., Chun, H. D., Han, G. W. \& Lee, C. H. Carbon Dioxide Capture with Accelerated Carbonation of Industrial Combustion Waste. Int. J. Chem. Eng. Appl. 2, 1, ISSN: 2010-0221 (2011).

108. Arickx, S., Van Gerven, T. \& Vandecasteele, C. Accelerated carbonation for treatment of MSWI bottom ash. J. Hazard. Mater. 137, 235-243 (2006).

109. Rendek, E., Ducom, G. \& Germain, P. Carbon dioxide sequestration in municipal solid waste incinerator (MSWI) bottom ash. J. Hazard. Mater. 128, 73-79 (2006).

110. Gunning, P. J., Hills, C. D. \& Carey, P. J. Commercial application of accelerated carbonation: looking back at the first year, In: Proc. Fourth International Conference on Accelerated Carbonation for Environmental and Materials Engineering Leuven, Belgium, April 9-12, 2013. 185-192 (2013).

111. Khaitan, S., Dzombak, D. A. \& Lowry, G. V. Mechanisms of neutralization of bauxite residue by carbon dioxide. J. Environ. Eng. 135, 433-438 (2009).

112. Yadav, V. S. et al. Sequestration of carbon dioxide $(\mathrm{CO} 2)$ using red mud. J. Hazard. Mater. 176, 1044-1050 (2010). 
113. Haselbach, L. Potential for carbon dioxide absorption in concrete. J. Environ. Eng. 135, 465-472 (2009).

114. Huntzinger, D. N., Gierke, J. S., Kawatra, S. K., Eisele, T. C. \& Sutter, L. L. Carbon dioxide sequestration in cement kiln dust through mineral carbonation. Environ. Sci. Technol. 43, 1986-199 (2009).

\section{ACKNOWLEDGEMENTS}

The authors acknowledge the technical support of Dr. Florence Lowry and Ms. Atiya Raza.

\section{AUTHOR CONTRIBUTIONS}

N.T. and C.D.H. designed the work, undertook the laboratory studies and interpreted the analytical data. They conceptualised and drafted the MSS. RSS contributed to biomass residues, research design, laboratory analysis and drafting the MSS. C.J.A. contributed to designing and critically reviewing the work. N.T., C.D.H., R.S.S. and C.J. A. approved the final paper.

\section{COMPETING INTERESTS}

The authors declare no competing interests.

\section{ADDITIONAL INFORMATION}

Correspondence and requests for materials should be addressed to N.T., C.D.H. or R. S.S.

Reprints and permission information is available at http://www.nature.com/ reprints

Publisher's note Springer Nature remains neutral with regard to jurisdictional claims in published maps and institutional affiliations. adaptation, distribution and reproduction in any medium or format, as long as you give appropriate credit to the original author(s) and the source, provide a link to the Creative Commons license, and indicate if changes were made. The images or other third party material in this article are included in the article's Creative Commons license, unless indicated otherwise in a credit line to the material. If material is not included in the article's Creative Commons license and your intended use is not permitted by statutory regulation or exceeds the permitted use, you will need to obtain permission directly from the copyright holder. To view a copy of this license, visit http://creativecommons. org/licenses/by/4.0/.

(c) The Author(s) 2019 